\title{
Creative Writing and Performance in EFL Teacher Training: A Preliminary Case Study
}

\author{
John Crutchfield
}

\begin{abstract}
The following case study was conducted in 2014 in the Department of Didactics of the Institute for English Language and Literature at the Freie Universität Berlin. It was conceived as a preliminary investigation for an ongoing qualitative research project called The Experience of Theatrical Performance in EFL Teacher Education. The purpose of this larger project is to study the effects of the experience of theatrical performance (i.e. live performance before an audience) on EFL teachers-in-training. For this preliminary study, qualitative data were obtained from a group of seven undergraduate English Education students in conjunction with a course focused on the use of creative writing in the EFL classroom. As part of the course work, the students produced a small number of original creative texts in traditional literary genres: a personal essay, two short stories (using $1^{\text {st }}$ and $3^{\text {rd }}$ person point-of-view), a poem and a short play. Each student also kept a Course Journal, in which he or she wrote daily in-class creative writing exercises as well as critical and personal reflections. The course ended with a Public Reading: the students presented their creative work before an audience comprised of peers, faculty, and members of the general public. The following paper considers in particular the students' personal reflections both before and after this Public Reading. What emerges is a coherent emotional and cognitive trajectory, determined in all of its moments by the theatrical event (as future, present, and past experience) of performing original creative work before a live audience. Because the investigation was conducted by a participant in the course (i.e. the teacher himself, a native English speaker born in the United States), the report also includes thick description of the intersubjective and intercultural contexts of the study, as well as ethnographic reflections on its limitations.
\end{abstract}

\section{Theoretical Background}

That aesthetic processes and experiences can significantly enhance the quality of learning in the academic classroom has long been recognized. ${ }^{1}$ This is

\footnotetext{
${ }^{1}$ In fact, the history of this idea reaches back to the Stoics, and has recurred periodically in European discourse on education ever since. It is essentially the argument, for example, of
} 
particularly true of the foreign language classroom, where the goal is not merely the intellectual mastery of a certain body of knowledge, but the embodied, impassioned and intuitive grasp of a new way of communicating; one might even speak here of a new way of being. From an anthropological point of view, this brings us into the realm of initiations or (as Arnold van Gennep famously called them) rites de passage: techniques for bringing about a holistic personal transformation, a "change in existential status" (Eliade 1975: 1). Hence the effectiveness of holistic activities, or activities involving the whole person, as that idea has come to be understood in recent scholarship. ${ }^{2}$

Preeminent among such activities is drama, by which I mean dramatic performance, an activity that by its very nature involves the physical body (and voice), the emotions, the intellect, and the imagination. ${ }^{3}$ In its most familiar form, however, Dramapädagogik-the systematic use of drama as a pedagogical technique-tends to eschew one aspect of performance that in other contexts would be seen as indispensable: the audience. ${ }^{4}$ We might ask ourselves what is lost from the experience of performance when the audience consists only of one's peers in the classroom? What, conversely, might be gained from fully embracing the public dimension of performance? In other words, what might be the pedagogical value of pushing our creative activities toward fuller artistic

Friedrich Schiller's famous series of epistles, Über die ästhetische Erziehung des Menschen, as well as of the later "Kunsterziehungsbewegung" associated with Ernst Weber (c.f. his Ästhetik als pädagogische Grundwissenschaft) and, perhaps most notably for the contemporary context, of the Waldorf Schools of Rudolf Steiner, who believed in the indispensability of an artistic approach to all subjects of study (c.f. "Pädagogik und Kunst" in Texte zur Pädagogik aus dem Werke von Rudolf Steiner: Anthroposophie und Erziehungswissenschaft). In the North American context, John Dewey looms large (c.f. his Art as Experience). A significant moment of recognition from the "scientific" side can be found in Frederick Turner's essay, "The Neural Lyre," in which he writes of the brain's limbic system: "Clearly if this system of self-reward is the major motivating agent of the brain, any external technique for calibrating and controlling it would result in an enormously enhanced mental efficiency. We would be able to harness all our intellectual and emotional resources to a given task... [T] his is exactly what an aesthetic education.... can do" (Turner 1985: 68).

2 "A holistic approach aims at taking into consideration the intellectual, physical, aesthetic, and emotional dimensions of learning" (Sambanis 2013: 245; my translation). This presupposes a certain anthropology, of course: a concept of the human being (and hence, of what constitutes a "whole person") that, in my view, has not yet been fully clarified in these discussions. Certainly one would not be in the global minority were one to object that any anthropology, and thus any pedagogy, that fails to take into account the spiritual aspect of the human being is woefully incomplete.

${ }^{3}$ For a cogent overview of the role of "performance" in this context, see Schewe (2013).

4 The most important other context is professional theatre. "[W] ithout an audience [the actors'] performances would lose their substance--the audience is always the challenge without which a performance would be a sham." (Brook 1968: 70). Scholars in the field of Performance Studies take this idea further, claiming that without an audience, there is no performance at all: "The audience is the dominant element of any performance" (Schechner 1988: 91); "Bodily co-presence means a relation of subjects. The audience is understood as co-players, who through their participation in the game-i.e. their physical presence, their perception, and their reactions-help create the performance" (Fischer-Lichte 2004: 47; my translation). The question is what constitutes an audience, or whether different kinds of audiences have different forms of "co-presence," etc. 
realization, namely, as theatrical event: performance before witnesses? ${ }^{5}$

And finally (and, for the purposes of the present study, most significantly): if such an approach can offer advantages for the foreign language classroom, might it not also have value for the training of foreign language teachers? Might it not, in fact, be of fundamental importance for such training? And this in a double sense: not only by way of preparing future teachers to make more effective use of the experience of theatrical performance in their pedagogy, but also by way of training them as teachers?

It will be understood that these questions rest on a basic premise, namely, that teaching is an art. If we take this idea seriously, then teaching, like all arts, requires artistic training appropriate to its form, i.e. training that encompasses not only such things as craft, technique, method, history and theory, but above all practical experience with specific creative processes. What sort of creative processes? In other words: exactly what sort of art is the art of teaching?

Since the mid-1970's, teaching has increasingly come to be understood as a performing or performative art, and teachers have come to be seen as performers, often in terms that suggest an analogy to improvisational acting. ${ }^{6}$ But while this view has gained significant ground in scholarly discussions, the reality in teacher training programs in both North America and Europe continues to reflect a very different set of values, one that has proven extremely resistant to change. Thiem (2014), for example, notes the paucity of aesthetic-affective training for future teachers of Spanish as a Foreign Language, and calls for a greater emphasis on this aspect in university curricula. ${ }^{7}$ It would appear that in general very little has changed since 1993, when Manfred Schewe, toward the end of his groundbreaking book, Fremdsprache inszenieren, wrote that, when it comes to aesthetic experiences and training, future teachers are "all too seldom [...] offered such opportunities" (Schewe 1993: 424; my translation). ${ }^{8}$

\footnotetext{
5 The classical Greek word theatron, from which the English word theatre and its cognates in other modern European languages derive, meant "place of witnessing."

${ }^{6}$ A short list of English titles is illustrative here: Teaching as a Performing Art (Lessinger Gillis 1976); Teaching as Performing (Timpson Tobin: 1982); Educational Imagination (Eisner: 1985); Artistry in Teaching (Rubin: 1985); and more recently: Teaching as a Performing Art (Sarason: 1999) and The Art of Foreign Language Teaching (Lutzker: 2007).

${ }^{7}$ A recent case study conducted with a group of sixty-three $1^{\text {st }}$ year English Education students in South Africa found that "the implementation of a drama-in-education progamme has the potential to improve English second language trainee teachers' oral confidence and simultaneously enable them to reflect on how the strategies could be implemented in their classes as potential teachers" (Athiemoolan 2013: 60). While this study moves us in a promising direction, it remains limited by an instrumentalist view of artistic processes, i.e. the view that art helps us do other things better. Hence here too the idea that teaching is itself an art continually slips out of focus.

8 The notable exceptions to this rule are teacher training programs in the artistic subjects per se: Art, Music and Theatre. But even here the focus remains largely on subject knowledge and teaching techniques rather than on the holistic development of the teacher herself as an artist.
} 


\section{An Overview of the Study}

In the summer semester of 2014, I undertook a preliminary, and admittedly very limited, investigation of the experience of theatrical performance in a course I taught for the Department of Didactics in the Institute for English Language and Literature at my home institution, the Freie Universität Berlin.

There were seven registered students, four men and three women, all of whom were in the Bachelor's program studying to become teachers of English as a Foreign Language in the Berlin school system. Officially, the course topic dealt with the use of creative writing as a pedagogical technique in the EFL classroom; as will be explained in greater detail below, however, the course required the students to experience not merely the artistic process of creative writing, but (more importantly for the purposes of this case study) also the performance of their own creative texts before a live audience in a Public Reading.

As an important part of the course-work, the students were asked to keep a Course Journal, in which they wrote responses to in-class creative writing prompts, reflections on their personal experiences with these prompts, and more free-form expressions of thoughts and feelings, particularly in relation to their experience of the Public Reading. In the case study which forms the substance of this paper, the students' Course Journals will be quoted extensively as the primary source of qualitative data, alongside my own Teacher's Log. ${ }^{9}$

The objective of the study, then, was to gain qualitative data on the student's subjective experience of theatrical performance. For this reason, my basic approach to the research, emphasizing as it did an inductive method and a privileging of emic perspectives (i.e. the student's own testimony as to their experiences), might best be called ethnographic. ${ }^{10}$ In what follows, then, a fair amount of attention will be given to matters of context in the form of thick description.

\section{An Overview of the Course}

While the course was not obligatory in the curriculum, it met a "proseminar" requirement. That is to say, the participants, at least theoretically, could have chosen another proseminar to meet the same requirement, and hence were to some degree self-selected, presumably either because the course topic interested them, or the meeting time (Wednesday evenings) suited their schedule and/or temperament. Alternately, as this was also the first course I taught as a new faculty member at the Freie Universität Berlin, it's possible that some students

\footnotetext{
${ }^{9}$ I call this a "case study" in the sense precise sense of "an intensive, holistic description and analysis of a single entity, phenomenon, or social unit" (Merriam 1988: 16).

10 "[E]thnography can be viewed as a qualitative research method that generally focuses on the group rather than the individual, stresses the importance of situating the study within the larger sociocultural context, and strives to present an emic perspective of the phenomena under investigation, with the categories and codes for analysis being derived from the data themselves rather than being imposed from the outside" (Mackey Gass 2005: 168).
} 
were simply curious to try a course from a new instructor who was also (as an American ${ }^{11}$ ) the only native speaker of English in the Department of Didactics. While it would be difficult if not impossible to assess the degree to which these factors may have skewed the participant pool toward certain personality types; or again, to assess the degree to which such a personality profile might consequently have tipped the data sample away from what could be considered "representative" or "average" for students in the English Education program at the Freie Universität Berlin or in Germany generally; nevertheless I feel they ought to be mentioned in the interest of more fully representing the circumstances of the study.

Several things are important to note about the course content. On one level, the course was structured like a standard undergraduate Creative Writing workshop, such as one finds in most U.S. colleges and universities today. Students were taught the basic craft of writing in the four primary creative genres: creative non-fiction (or personal essay), fiction, poetry, and drama. Each unit involved appropriate in-class writing prompts, mini-lectures on craft from the instructor, literary readings from an anthology or course-pack, oral presentations, formal assignments to be turned in plus group workshop of these, and finally, a Public Reading before a general audience. All or most of this would have been familiar to anyone who had taken a class in Creative Writing at the college level in the United States. Viewed from this perspective, the course participants were treated like any students who had enrolled in a class in which they hoped to learn the art and craft of Creative Writing, with the key difference that these were students for whom English was a second (or third) language. ${ }^{12}$

Thus on one level, the course was about artistic training. But this "workshop" level of the course was contextualized by another level, which I will call the "laboratory" level. That is to say, the experience of the "workshop" was itself taken as the object of investigation for the "laboratory," which ran concurrently, or rather meta-currently, with it. Since the participants were not, in their own minds at least, students of Creative Writing, but rather, students of English Didactics, their chief interest, at least initially, was presumably to learn not the art and craft of Creative Writing for aesthetic purposes, but the effective use of creative writing activities as a set of pedagogical tools in the English classrooms in which they would one day be teaching. Their primary or initial interest in Creative Writing, then, could be described as practical or instrumental rather than aesthetic. Hence viewed as "laboratory," the course was intended to serve as a way for the students to try out upon themselves various creative writing exercises, reflect upon their personal experiences with these exercises,

\footnotetext{
${ }^{11}$ Here and throughout, I use the term "American" in the restricted political sense of "U.S.American" or "Citizen of the United States of America." I do not mean to imply thereby that citizens of Canada or of states in Central and South America are not also "Americans" in the broader, geographical sense of the word.

12 Certainly this last circumstance influenced (by limiting) the amount of material that could be covered. Whether and to what degree this also influenced the way the course material was taught will be the subject of a future investigation.
} 
and evaluate the potential usefulness or interest of these exercises for the EFL classroom.

The chief instrument for this work was the Course Journal. Each class meeting began with a series of three in-class writing prompts, which the students wrote out by hand: 1) a prompt similar to what might be used in an actual Creative Writing workshop; 2) a reflection prompt, in which the students were asked to reflect upon their experience with doing the first prompt; and 3) an evaluation prompt, in which the students were asked to critically assess, to the best of their ability, the potential usefulness of the given exercise for an EFL classroom. These responses were then shared, on a voluntary basis, in discussion. ${ }^{13}$

To sum up then, the course was conceived as two things at once: an introductory artistic training in Creative Writing, and a laboratory in which this training became the experiential means by which the experimenters experimented upon themselves.

\section{The Rationale}

Laying out the rationale for this two-level structure (a Creative Writing Workshop nested within a Teaching Laboratory) brings us to a third level, the level of investigation that constitutes the framework for this case study proper. In a word, the overarching intention with the course was to give participants a certain kind of aesthetic experience. The course, as research instrument, was designed to discover what, if any, personal benefit future teachers of English as a Foreign Language might gain from embracing the full artistic process of creative writing, from composition to revision to public presentation, and reflecting upon this experience critically. Hence at the level of the Workshop, the participants experienced something like what any Creative Writing student would experience given similar tasks. In many instances, as we shall see, this experience involved feelings of pleasure of the kind often associated with play, with creative activity and self-expression, or with any task that involves a significant challenge met and overcome. At the level of the Laboratory, what the participants experienced was a deepening critical self-awareness of themselves as future teachers: reflecting upon their own experiences in the Workshop, they were able to evaluate the usefulness of these experiences for their own future students. At the outermost level, the level that primarily interested me as investigator, these first two levels of experience dovetailed into what I will provisionally call a transformative experience of self-discovery. According to their own testimony, as we shall see, the students became more self-aware, more self-confident, more creative, more empathetic-in short,

\footnotetext{
13 The other "workshop" related aspects of the course-the oral presentations on the course readings, the discussions that followed, the group critiques of formal assignments, and the Public Reading at the end of the term-all of these were also reflected upon and evaluated, albeit in a less systematic way, from the "laboratory" point of view.
} 
more authentic ${ }^{14}$ - and hence, I would suggest, better prepared to enter their chosen profession. The key to this aspect of the course was, as the students' responses show, the moment of theatrical performance, i.e. the end-of-semester Public Reading.

In this sense, we might characterize the students' experience in terms of initiation, modest in scope to be sure, and thoroughly secular, but one that perhaps brought them a few steps closer to embodying the idea of teaching is an art.

\section{A Note on the Data}

I will draw on two sources of qualitative data here: 1 ) What the students wrote in their Course Journals, and 2) What I wrote during the same period in my Teacher's Log. Of particular interest will be the period immediately before (approximately one week) the Public Reading, and immediately after it (again approximately one week).

In addition to the weekly in-class prompts, many of the students also wrote outside of class, either as expansions on or continuations of their initial in-class responses, or in the form of their own independent work. These entries were to be made as much as possible in English, as English was the lingua franca of the course; although here I made it clear that this was no fast and hard rule, and that "reverting" to German might even be desirable with certain prompts. The Course Journals were turned in to me at the end of the term, and constituted an important requirement for passing the course. The students knew this from the beginning (since it was clearly stated in the syllabus, and I made continual reference to it throughout the semester); but the only guidelines I gave were that they approach each prompt in the spirit of an experiment: that they "give it a try."

This turned out to be rather difficult for several of the students, at least initially. There were many questions in class about what I "expected," and whether I would "count off for spelling," etc. It quickly became clear that few if any of the students had previous experience writing creatively within a formal or educational context, and that they were quite uncomfortable with the idea of turning in something to an instructor that was raw, unpolished, fragmentary, and to varying degrees personal. One student was concerned enough about this to type up (and presumably, revise or at least edit) his entire Course Journal before handing it in. I never saw the handwritten original.

Thus it might appear that the primary source of data for the study is far from pure. The students knew that what they were writing would be read by their instructor and would count toward their grade. Normally this would tend

\footnotetext{
14 Yes, I dare take up this much-maligned word. As I have come to believe, partly as a result of this study, a concept of personal authenticity is indispensable for any serious discussion of the experience of performance. I use the term, however, not in the quotidian sense of "genuineness," much less in the philosophical sense of metaphysical "realness," but in the pragmatic, social-psychological sense of feeling congruent with one's self (cf. Rogers 1961).
} 
to mean a certain amount of "tailoring" (whether conscious or unconscious) toward what the student assumes or imagines will please or impress the instructor. This, at least, I anticipated; therefore I went to certain lengths to emphasize, both in the syllabus and orally in class, that I graded the Course Journals only on the basis of what I called "commitment," i.e. whether the students made what I considered to be an honest effort, be it a response to an in-class prompt or to a reading assignment, a personal reflection or mere "scribbling" as part of their own artistic process. I emphasized that I was not judging them here on the aesthetic quality of their work (that was reserved for the Formal Assignments), much less on the neatness of their handwriting or the correctness of their written English. The intention of all this was to take the pressure off: to ensure, to whatever degree possible, that the students' responses were spontaneous and honest.

I made a concerted effort, moreover, to adapt my teaching style to this larger aim. As the excerpts from my own Teacher's Log will show, I sought to support the atmosphere of honest expression by strategically decentering my own point of view during the class meetings: I shifted my rhetorical position in discussion, often playing "devil's advocate" to move the discussion forward when I felt it had stalled. Rarely did I express my personal convictions, and when I did, it was always presented as one more point of view among many possible points of view.

In conjunction with this, I repeatedly called into question the very premises of the course itself, and even of my own role as teacher. I quite deliberately sought to "dethrone" myself from the traditional position of outward authority in which instructors at German universities (and elsewhere) are so often pleased to sit. ${ }^{15}$ In short, I did whatever I could think of to free the students from the twin burdens of fear and flattery that too often come with the teacher-student relationship in a traditional educational context, where rewards and punishments are meted out according to rules that are at best only superficially objective and fair. ${ }^{16}$

That the data are by nature "subjective" is clear enough; but my intention was to render them, to whatever degree possible, "qualitative" i.e. to make them an accurate representation of the subjective states of the students, hence empirically valid for the purposes of the study.

\footnotetext{
15 An important discussion early in the class addressed precisely this theme: what is real authority? Is authority inside the classroom different from authority outside the classroom? And what does it have to do with authenticity? This is a theme to which I return below, especially in its connection to creative writing and performance.

16 This dynamic works both ways, of course. Many teachers also oscillate between fear and flattery vis-a-vis their students. At colleges and universities in the U.S., this relation is now institutionalized by the nearly ubiquitous practice of end-of-semester course evaluations: students evaluate their teachers according to their perception of what has happened in the classroom. As might be imagined, students approach this administrative task with varying degrees of seriousness. Nevertheless, depending on the institution, these evaluations can play a significant role in contract negotiations for both contingent and tenure-track faculty. There is thus a strong economic incentive to teach in ways that please students (including "grade inflation"), which may not be the same thing as teaching well.
} 


\section{A Note on the Researcher}

In certain ways, the freedom to "play" with my own authority, as described above, was an American privilege: first as a native speaker, and second as the inheritor (for better or worse) of a certain cultural style. Depending on one's own point of view, that style might seem "natural," "free and easy" and "spontaneous"; or it might seem "lazy," "slack" and "undisciplined." In other words, if my strategic decentering etc. succeeded, this may well have been due at least in part to certain allowances the students granted me by virtue of my (probably to them quite obvious) Americanness. If this is the case, then it is possible that the students might indeed have "tailored" their responses, and in a more sophisticated way than I anticipated, for example by emphasizing the "anti-authoritarian," "critical," "irreverent" or simply "free-wheeling" impulses that they would not normally have thought worthy of expression, but that they imagined would find a receptive audience in me.

All of this raises the relevant question of my own point of view as teacher/researcher, which cannot easily (and, I would argue, should not) be separated from my cultural and professional identity as an American teaching at a German university. First of all, not every American would want to do such a thing. Moreover, I am not even primarily an academic, but a professional writer and theatre artist who happens to have had a parallel career as a teacher of Creative Writing, Literature, Film Studies, and related fields at a variety of colleges and universities in the U.S. Doubtless this places me at a certain remove from the highly professionalized and compartmentalized world of German academia in general and in particular of teacher training in the German university system, to say nothing of the school system toward which that training is purportedly aimed.

As I hope to show, however, this outsider-in status is in fact of critical importance for the work of this study. In order to explain this, it will be necessary to make a brief excursus in "comparative ethnology" with an eye to the structural and cultural dynamics that formed the context of the study.

There are, to say the least, significant differences between the German education system in which I now work and the system in the U.S. in which I was educated, and these are deeply rooted in the two cultures. One effect of these differences is that, whereas students at colleges and universities in the U.S. have, over the course of the last twenty years, generally come to see their education as a product they (or their parents) are purchasing for consumption, and hence to approach it as if they could do with it as they please (for instance, by ignoring all or parts of it, or by reshaping or "customizing" it to suit their personal goals, interests, values, or preferences), German students tend to view their education in monolithic terms, as a necessary and more or less rigid set of tasks that must be completed before one can enter any kind of legitimate profession. This is true for artists no less than for medical doctors. One sees this in the classroom: in comparison to American students, German students tend to be passive, polite, serious, obedient, and very focused on doing things 
correctly. ${ }^{17}$ Why are these general tendencies significant? For one thing, they help explain why a German student might feel anxious about an open-ended or creative task like writing a poem or keeping a Course Journal, while an American student will either embrace it as a chance to express himself for a grade, use it for his own purposes, or flat-out refuse to use it at all.

Part of this is certainly a matter of national heritage, or rather, of ideology. One could point to that seemingly unshakable article of American faith, according to which "any child could become President." Factors of class, ethnicity and geography aside, an American youngster will typically reach puberty and beyond with the intact belief that he or she has special talent or potential, perhaps even genius, whether in the fine arts or in some other area of cultural, economic or political life. (Thus the prominence of terms like "opportunity" in political discourse.) For teachers of Creative Writing at U.S. colleges, the task is often not so much to encourage students to be creative and to believe in the innate value of what they have to say (they're already fully convinced of this), but to help them separate the wheat from the chaff in their own writing, to help them find what is truly original and distill it from what is merely imitative, and to teach them the discipline, and in particular the self-discipline, of being a creative writer, in short: to teach them a respect for the art of writing.

For German students, the situation is almost inverted. Here, the teacher faces young people who have largely been taught to mistrust their imaginations and emotions and to undervalue their individual talent. To them, a Schriftsteller (and certainly a Dichter) is a great and rare human being, a person of exceptional talent (for which he may suffer), a significant figure in the life of the culture, someone with important things to say. ${ }^{18}$ The art of writing seems no more within reach for most students than the art of composing a symphony. Respect for the art itself is fully developed, but externalized, projected onto others. What's most often needed is encouragement in seeing and appreciating one's own creativity.

Thus one of the great challenges for me as teacher in this course was to adjust my expectations to the actual students in front of me. This was particularly true, as shall be seen, when it came to the end-of-term Public Reading. In all previous Creative Writing courses I'd taught (in the U.S.), this opportunity to share one's

\footnotetext{
17 Nota bene: These are, of course, generalizations based upon personal observation and anecdotal evidence. Even in my own experience, exceptions abound: some of my most engaged and "active" students have been German, and some of my most disengaged, passive, and (to all appearances) intellectually inert students have been American. I suppose what we're dealing with here is a spectrum of behaviors, along which individual students tend nevertheless to clump according to nationality. And this is to say nothing of how, for example, English, French or Italian university students might widen the spectrum in one direction or the other, or fill in the gaps between.

18 Anecdotal evidence suggests that this may be changing in Germany now, as part of the general evolution away from print culture. Compared to the U.S., however, that evolution has been slow. Books in Germany are still printed and bound with high quality materials, and one still finds a significant number of national print newspapers, any one of which would make the New York Times, The Washington Post, The Wall Street Journal etc. seem quite sparse indeed-and throughly commercial.
} 
work publicly was something the students were, with very rare exceptions, eager and excited to take advantage of. The participants in the course at the Freie Universität Berlin were, by contrast, extremely reluctant-and in some cases openly opposed to the idea of any kind of public presentation. Perhaps I should not have been surprised; for in addition to the cultural factors sketched above (or perhaps as a consequence of them), these students had, by their own testimony, no previous experience with the performance of original creative texts. This too has its reasons.

In the U.S. system of higher education, with which I am much more familiar, it is by no means unusual to find professional artists among the teaching and research faculty. American students taking a course in Creative Writing at a reputable college or university (or even at a private or well-funded public high school), for example, might with justification expect their instructor to be a published writer. At an "upper tier" private university like Harvard, that instructor would also be expected to have a Pulitzer Prize, National Book Award, or MacArthur "Genius Grant" under his or her belt, as well as numerous titles for sale in the campus bookstore. In Germany, by contrast, the general rule has been to separate fine arts training from higher education in the humanities. There is, for instance, no formal curriculum in Kreatives Schreiben at the Freie Universität Berlin, much less an actual major in it. One would have to attend one of the specialized Kunsthochschulen (state-run conservatories) in order to obtain this sort of training, which would also be deeply integrated into the professional world of literary publishing and producing. ${ }^{19}$ Hence the last place in Germany one would expect to find a practicing writer, or artist of any kind, would be a Department of English Didactics; and if he were there, he would do well not to assume his students had any prior experience with art in a school context. Almost by definition, they would not have: for if one is working on a BA in English Education, it is because one has successfully followed a certain curricular / career path from very early on, possible as early as middle school, and that path rarely, if ever, makes any sort of detour through the territories of art. Those territories are by and large terra incognita.

\section{A Word on Method}

The students' Course Journals, which were collected at the end of the term, proved with few exceptions to be extremely rich in information. For the purposes of this study, I have restricted myself to examining their responses to only two of the many prompts I gave them:

\footnotetext{
19 See for example the Universität der Künste Berlin (www.udk-berlin.de), which offers a highly selective major in Dramatic Writing ("Szenisches Schreiben"). "The list of graduates... reads like a veritable Who's Who of contemporary drama," the web page proudly proclaims. "Even in the course of their studies, many of our young authors work with a publisher or a professional theatre, and win fellowships and prizes. Applicants are accepted only every two years for this course of study, the most successful of its kind in Europe" (my translation).
} 
1. "Express as fully as possible your thoughts and feelings right now about the upcoming Public Reading."

\section{2. "Reflect upon your experience with the Public Reading."}

As noted above, the first prompt was given a week prior to the event, the second a week after it. The students' responses were excerpted from the Course Journals and collated, so that they could be easily analyzed both vertically (in terms of the group's experience) and horizontally (in terms of individual students" experiences) across the "divide" of the Public Reading.

These written responses were first transcribed and anonymized. ${ }^{20}$ I then scanned them for significant or recurring themes, and particularly for linguistic indictors of emotion. (In one case, I included material communicated to me separately by email, i.e. outside the Course Journal, since the explicit topic of the email was the student's participation in the Public Reading.) After these themes had been collected, listed and codified, a second pass was made over the full transcription, during which individual occurrences of the themes were notated and tallied. ${ }^{21}$

This procedure was performed twice: once for the entries written prior to the Reading (i.e. in response to the first prompt above) and once for the entries written after the Reading (i.e. in response to the second prompt above). Thus I arrived at two parallel lists of thematic descriptors, as well as at a numerical tally of their frequency of occurrence.

I then assessed these data "vertically" in terms of what they say about the students' overall experience with the Public Reading, before and after. The idea here was to arrive at a general or global picture of the students' subjective experience. And finally, I tracked selected individual students' experiences "horizontally" across the event of the Public Reading. As will be seen below, there was significant variation here.

The data collected from the students were then placed against the backdrop of my own experience during the same period as recorded in my Teacher's Log. This was done in the interest of triangulation, i.e. with an eye to discovering both a) points of convergence, in which my experiences and perceptions confirmed the students' feelings, and b) points of divergence, in which my experiences

\footnotetext{
${ }^{20}$ Names and titles of original texts, wherever they appeared in the Course Journals, were removed, as were all references to the gender of the writer. Likewise, I have used the pronoun "he" throughout the following summary, regardless of the actual gender of a given participant, in addition to making other minor verbal adjustments in order to insure anonymity. Furthermore, I have corrected careless errors as well as grammatical and spelling errors where these bore no relation to (or obscured) the content. Where there were questions of legibility, I have inserted the symbol [?] after my best guess as to the intended word. Other graphic idiosyncrasies (such as underlining, dashes, arrows, etc.) I have retained, since these do relate to content, either as emphasis or as logical markers.

${ }^{21}$ It is important to note that in some cases these themes took the form of words the students themselves used ("nervous," for example, which in the list I nominalized as "nervousness" ); in other cases, a certain amount of abstraction was necessary (for example: when students wrote about not knowing whom to invite to the Reading, or about being worried that no one would come, I rendered both as "concerns about the audience").
} 
and perceptions contradicted (or merely inflected) the students' feelings. In the Conclusion, an attempt is made to arrive at an interpretive "vector" of these collective experiences, and to offer a summary reflection on what they might tell us in general about the experience of theatrical performance for foreign language teachers-in-training.

\section{What the Students Wrote}

The First Prompt

In answer to the prompt, "Express as fully as possible your thoughts and feelings right now about the upcoming Public Reading," the students' responses tended to emphasize one or more of the following themes (in order of frequency): ${ }^{22}$

- nervousness

- concern about the audience

- concern about the quality of the work

- excitement/anticipation/curiosity

- fear/terror/resistance

The most common theme by far was nervousness: five of the seven students used the word in their responses, in some cases multiple times.

I feel that the public reading is a huge task for me. I can feel the nervousness coming up and I am afraid that this nervousness will become so strong next week that I will simply be rushing through the play and spoiling what I want to read out. It is a play. Having this in mind, I expect myself to represent a character and to read out the text as if I were this character myself. [...]But my nervousness can make me [...] feel shy and shaky so that I run the risk of misrepresenting the character and the play. How can I read out something in an aggressive and provocative manner when I am feeling meek and insecure. I still do not know how to deal with that nervousness. But my intention is to make this nervousness useful to me instead of giving in to it by simply reading out monotonously without expression. [Student 1]

Thinking about the public reading, I am unsure about what to read. I haven't yet written a piece that I'd like to present. So I am also nervous if the audience will appreciate my writing and consider it worth their time to have come to the reading. Yet, I also feel thrilled thinking about reading a piece that I really like (if I have one by the time of the reading), and I am excited to see that I have moved my audience. [Student 2]

\footnotetext{
${ }^{22}$ As will be seen in the excerpts below, however, these themes were often clustered together or to varying degrees "associated" in the students' minds.
} 
I feel a bit nervous and excited about it, but I think when this moment actually appears, it will become more and more intensive. And the thing is when I am nervous I can't read that properly. What makes me most excited is the audience that is looking at me all the time and expecting something that I may not fulfill. I also feel some kind of pressure to do everything right. [Student 3]

In all three excerpts given above, the students explicitly link their nervousness to their imagination of the performative moment, and in particular to their desire to have an effect on the audience. Student 1 is most concerned that his nervousness will prevent him from doing justice to his text when he presents it to the audience. He is worried that his nervousness will cause him to read "monotonously." What is interesting in his case is that he considers his nervousness not as something to be banished, repressed or overcome, but as something he must make "useful" for his performance.

With Student 2 the picture is slightly more complex. He is first concerned about the inherent literary quality of his text, but he quickly connects this to nervousness about whether or not the audience will "appreciate" his writing and consider it "worth their time." Yet in the same breath, he is excited to discover whether he will have "moved" his audience. We will see this investigative impulse born out in Student 2's reflections post-Reading as well.

Student 3 echoes some of Student 2's concerns, singling out in particular what he imagines will be the audience's expectations, and questioning whether he will be able to "fulfill" them, since his nervousness makes it difficult for him to "read properly"-something he presumably knows from past experience.

For some students, this feeling of nervousness escalated into fear, and in one case, into actual "terror." One student, who was very vocal both in class and to me privately about his aversion to the whole idea of the Public Reading, and who at several points stated flat-out that he simply would not participate, later wrote me an email shortly before the event:

I have been think [sic] about the public reading a lot these days and I have come to the conclusion that I'll pluck up my courage and go for it. I am actually terrified by the very thought of it to be honest but it's something that I don't think I'll ever get the chance to experience again. [Student 4]

That this student frames the issue in these terms is significant for a number of reasons. "Courage" and "terror" are of course not only moral but existential categories, and Student 4's use of them here indicates the degree to which he feels himself personally at stake in the question of the Public Reading. Clearly for him, the prospect of performing original work in front of an audience presents a deep, one might even say fundamental, challenge. There will be more to say on this when we consider Student 4's individual experience horizontally (see below).

Student 4 was not the only student whose nervousness was intense enough to produce strong feelings of resistance, at least at first, to the prospect of the Public Reading: 
Honestly I don't like it and I do not want to participate in it. I do not want to be pressured [?] in something! It might be a good idea - but only for those who like such things to do. It is not that I feel ashamed... I feel simply not ready for that, not really prepared... it might be nervousness. [Student 5]

Here the apparent issue is not existential terror, but a simple feeling of unreadiness. That the student mentions shame, however (albeit in the form of a denial), is interesting in its suggestion that something about the idea of the Public Reading poses the question of very personal feelings of worth.

For both Student 2 and Student 3, however, nervousness (generally considered a negative or unpleasant emotion) tended to be linked to the generally more positive emotion of excitement. Student 2 even uses the word "thrilled."

Conversely, one student was unique in his alleged lack of any affect whatsoever. Early on, as I recall, the student had verbally expressed reluctance, but now (a week before the Public Reading), he seems to have entered an affectless zone, albeit one that, in a meta-emotional or apperceptive way, he found disturbing:

It's weird, now that I think about the public reading, there's no emotions coming up. I feel rather indifferent and wouldn't mind doing it now. But I dislike that I don't feel excitement. I would love to very much look forward to it because then it could maybe build some pressure or release energy for revising my texts. I feel like I should start revising the drafts. There is just so much stuff going on at the moment that I can't find the time and peace of mind to look into it again. [Student 6]

Shortly before the Public Reading, this student revisited the question of affect in his Course Journal, and discovered more to say:

Momentarily, I very much dislike the thought of a public reading. The past weeks have been sort of rough and exhaustive and I don't feel tempted by the thought of presenting myself and my work in public... I kind of feel vulnerable and self-conscious, stressed out and depressed. There seems to be little to no filter of happenings from the outside reaching my inside. There has been the thought in my head to cancel [?] the whole thing. But I feel as if that would not be fair. As if I'd let the others down by that. [Student 6]

These last remarks are interesting for several reasons; first, the student locates the source of his disinclination to do the Pubic Reading in personal circumstances ("The past weeks have been sort of rough," etc.), which have left him feeling "vulnerable and self-conscious, stressed out and depressed." These feelings make the thought of performing unpleasant to the point of wishing he could cancel the event or simply decline to participate. What the student seems to be experiencing is an irruption of personal life into professional life, and a consequent disruption of one by the other. Unlike Student 5, who looks outside himself (at least initially) for the source of his discomfort and characterizes 
the Public Reading as an unwelcome coercion, Student 6 seems aware that his resistance to the Public Reading is essentially an internal affair having to do with his own emotional situation. The key concept here is the feeling of vulnerability, which arguably lies at the root of the feelings of fear/terror, nervousness and excitement which the other students observed in themselves.

Equally interesting is the way Student 6 braces himself to go through with the Public Reading anyway. He understands the problem in essentially moral terms: it "would not be fair," he writes, for him to refuse to participate, and he feels he would thereby "let the others down." In other words, Student 6 feels a responsibility to the other students to do his part, much in the manner of any member of a team or ensemble. Despite what appears for this student to be significant personal and emotional duress, the show must go on.

Only one other student made explicit reference to unrelated circumstances as a source of internal stress vis-a-vis the Public Reading:

HAVE to prepare for my other 4 exams in the same week $\rightarrow$ still haven't learned enough to pass the example test!... I am losing time that I could prepare for exam but of course EFL-Course is more interesting than learning. [Student 7]

The other most prominent themes were concern about the quality of the texts and concern about the audience. Student 2's remarks (above) are illustrative of both concerns: whether his work was "worth" the audience's time, and whether the audience would be "moved" by his performance. He addressed both themes at greater length in his Journal shortly before the Public Reading:

It's two hours before the reading now, and I start to feel excited. At first, I was very convinced to do the public reading because I thought of it as a nice way to round up the course and experience the thrill of a public performance. Yet I hesitated to invite a friend because I wasn't totally convinced that my works are ready to be presented in public. Reluctantly, I told some selected friends about the event, then I began to change my mind and told more people about it because rather than reading to an audience that was entirely selected by John Crutchfield, I'd like to share this experience with some of my friends, too. Right now I am excited to read my works, also a bit nervous about my performance, but curious about the audience's feedback. [Student 2]

The question of whom to invite to the Public Reading, and the related fear that no one would attend, appeared in several Journals. Student 7 wrote:

$\rightarrow$ feelings: skeptical - nobody is going to come - I do not know whom to invite and I do not think anybody will be interested to come, especially at this hour. [Student 7]

Closer to the date of the event, the student wrote: 
-Still I do not know whom to ask ${ }^{\circledR}$ everyone [?] is too busy - do not know anyone from Uni who's still around at that time, so it is not inconvenient. [Student 7]

To sum up the students' self-reported feelings prior to the Public Reading, one would have to say first of all that none of them claimed to be "looking forward" to it. The most positive feelings were "excitement," but this feeling was in all cases tempered by or mixed with other, more negative emotions. Only one student (Student 3) reported feeling "confident" about his part (and that only after he had had a chance to rehearse in class). For the majority, the feelings ranged from nervousness to terror to outright resistance. Three of the seven seem seriously to have considered backing out, or at least to have wished they could have done so in good conscience.

What is most significant for our purposes here is the fact that all of these feelings are directly or indirectly relatable to the public, performative nature of the planned reading, that is, to its essence as theatrical event. It was above all the prospect of a live audience's witnessing the reading that provoked the strongest emotions.

The Second Prompt

Now let us turn our attention to the event itself. The final prompt the students were asked to write in their Course Journals required them to "reflect upon their experience with the Public Reading." It should be noted that, in the end, despite some strong initial resistance, all seven students took part in the Public Reading. ${ }^{23}$ Here the prominent themes were as follows: ${ }^{24}$

- pride

- fun/enjoyment/pleasure

- self-knowledge

- ensemble feeling

- relief

- nervousness

- knowledge of performance/subject

\footnotetext{
23 The Public Reading took place in the evening at a small student café in the main humanities classroom building on the Freie Universität campus. The atmosphere is comfortable (with well-worn couches and chairs, large windows, potted plants, newspapers and books lying around, and, by my arrangement with the staff, drinks and sandwiches available for purchase). My intention was to find a performance space that would be most conducive to an intimate connection with the audience, as well as to a sense of informality and hence (I hoped) of being at ease.

${ }^{24}$ Note that the number of significant themes is greater than for the first prompt. This would seem to suggest either that the students' experiences were more various or individual, or that they simply had more to say after the event than before.
} 
- courage

Student 1's entry, which I will quote at length, gathers many of these thematic threads at once:

I feel very proud of myself for having read out the play exactly in the way I wanted to. I was terribly nervous but used that nervousness by building it in with my introductory speech and thus dealing with it directly. It absolutely amazed me how much fun that was to read out to an audience what I had written. Of course, it was helpful to me to be surrounded by other people reading out with me. I was part of a group and therefore felt more comfortable than I would have when I would have stood or sat alone in front of that audience. I enjoyed it [...]

Furthermore, reading out a play made me more attentive and aware of how theatre works and how important it is who reads dialogues and how they are read. Even a slight overemphasis or a tiny change in tone can spoil or save the whole content of a play and can make it a dramatic failure or a big success.

Yet, the most important lesson I learned on Wednesday is that we all should appreciate and respect what we do. Normally, we tend to miss opportunities to show our individuality and our inner selves. I think we do that because we are afraid of being considered a show-off or knowit-all. Normally, when standing in front of an audience, I used to rush through all I wanted to say because I was lost in the fear of being boring. Formerly, I have the impression, in my way of speaking and moving, that I did not respect or like what I was doing or saying. On Wednesday, I replaced this wrong strategy by a new one: I took my time, paused several times (strange feeling, by the way), looked directly in some listeners' eyes and thus generated more confidence and respect in my performance. Make your listeners attentive by entertaining them and by addressing their emotions. That is the first rule. The second is: Enjoy what you are doing. And the third is: Be brave enough to stand out from the crowd and be brave enough to enjoy being in the centre. [Student 1]

Student 1 seems to have been quite surprised ("absolutely amazed") by the enjoyment he felt in presenting his work to an audience. One might also speak here of a sense of creative empowerment as a result of the feeling of a successful performance. By his own testimony, Student 1 learned extremely significant lessons about the value of his own creativity and the importance of possessing the courage to embrace, develop and manifest it in public ways.

Although none of the other students' reflections combine so many themes quite as cogently as Student 1's do, his experience finds clear parallels among his classmates. Student 2 also surprised himself in the performance, and experienced both a pride and a satisfaction (the word he uses is "joy") similar to what Student 1 experienced:

The public reading was strange to me in two ways: I was very nervous before I stood up and walk to the podium to read, but as soon as I sat down 
I was totally calm, so calm that it was somehow frightening. Second, I wasn't very happy with the quality of my work before the reading, but while reading I got to like it a lot, I even felt an inner joy about the craftfulness of my poem and story.

Afterwards, I felt both relieved and proud and I was especially happy that some of my friends had witnessed my reading. I think that one of the most important things I have learned from the reading is that I need an audience for works that I'm writing, certainly not all works, but those works that occupy my thoughts. Knowing that there will be a public reading intensifies my efforts to improve my works, the reading itself then finishes the creative process. [Student 2]

These remarks point once again, and now quite explicitly, to the importance of theatricality. The performance or public presentation before an audience not only "intensifies" the artistic process in a proleptic way (i.e. as anticipated event), but also, as Student 2 writes, "finishes" that process. In other words, for Student 2, public presentation is not merely a supplement or garnish to the artistic process, but a necessary culmination or telos: it is above all there, in the feedback loop of live performance before witnesses, that both artist and work receive validation.

The theme of ensemble feeling, which Student 1 addressed ("I was part of a group and therefore felt more comfortable"), was taken up at greater length by Student 6 , and seems to have played a significant role in determining his experience of the Public Reading:

I'm glad I participated in the Class Reading. It went better than I thought and I also felt comparatively comfortable doing it. It made me realize how close we have grown as a group. And even if it may sound cheesy, it was not "me" doing it but "us" presenting "our" work. [...] The general feeling of self-consciousness which I felt in the last weeks did not really come into play, as the good connection within the group was uplifting. [Student 6]

As I will discuss below, these remarks surprised me when I first read them, since from my point of view as teacher, the class had not seemed particularly well-integrated as a group prior to the Public Reading. The students did not, even late in the semester, seem to know much at all about each other personally, and there were many moments in class of apparently serious disagreement, dissension, and disengagement. In a way that struck me as quite foreign, the students spoke to each other in class rather "abstractly," tending to avoid making any explicit reference to each others' personal life. I noticed as well that after class, they tended to disperse in different directions, and with only a few exceptions, never lingered to chat with each other. ${ }^{25}$

\footnotetext{
${ }^{25}$ Granted, while these behaviors are at least in part attributable to cultural and social factors (Berlin is by no means a "college town," and the Freie Universität Berlin does not much resemble a North-American-style "college campus," with dormitories, sports facilities, bucolic quads, etc.), nevertheless it is also possible that this particular group of students was, for whatever reason, just not especially cohesive.
} 
If these perceptions of mine are accurate, then one must assume that something happened in the last weeks of class leading immediately up to the performance, if not in the performance itself, to forge a personal bond among the students. It is certainly worth considering the possibility that, given the strong emotions about the Public Reading as the event approached-i.e. the fear and apprehension detailed above, which were not merely described in the Course Journals but also openly discussed in class-there was a communal sense of an approaching ordeal, something that would require courage and commitment from everyone in order to "survive." 6

To be sure, differing "degrees" of courage were required from different students, because the degree of fear was different. For some students that fear boiled down to no more than the nervousness that is perhaps natural before any public presentation of self; but for others this fear was nearly paralyzing. What no one seemed to doubt was that this Public Reading was a significant event, one in which something was "at stake." The reality of this significance, embodied in the audience of people sitting in the room on the night of the Public Reading, presented the class with a common challenge. Having heard and read each other's work in class, having workshopped it with an eye toward revision, and having rehearsed it the week before the event, they knew each other's strengths and weaknesses and thus were prepared to position themselves as "allies," to root for each other's individual success, which of course also meant the success of the Public Reading as a whole.

Apart from Student 6, the two students who were initially most resistant to the idea of participating in the Public Reading were Students 4 and 5. Both began by flatly refusing to participate. Both eventually came around of their own accord, albeit very late in the game (one and two weeks, respectively, before the event). While their remarks confirm the general experience of the Public Reading, they also focus on specific issues not addressed by the others. Student 5, who seemed (from my point of view) to put the least effort into preparing for the Public Reading, and who read the shortest piece (a single poem of about fifteen lines), wrote of his frustration at not being able to express himself as he wished:

To say what you feel about a thing or a situation normally needs more than five minutes or even less. Presenting your personal feelings is something you need time for: time to develop your thoughts and ideas.

Our presentation night was, I feel, a success. But I think those who listened to us had only little time to grasp what we, each individual, wanted to tell them regarding our topics. I, for one, could not say what I really wanted to tell the audience; what the listeners got was only a hint from my life. Personally, I did not feel nervous, etc., rather, I felt that much more things should have been said on the topic. (Of course, it was my decision to make my poem so short.)

\footnotetext{
${ }^{26}$ I deliberately use the word "ordeal" here in the ritual or initiatory sense familiar from van Gennep (1908), Eliade (1925), et. al.
} 
What I felt was that to express what you really feel you need time to find the right words and that letting the others take part in your life (regarding the topic) you can teach them how to deal with similar situations etc. or simply give them ideas can lead them in the right direction. The point I am making here is that I wanted to express more; I wanted to let the audience take part in what I felt, but felt that all I said remained on the surface. [Student 5]

All of this is written without irony. Though what comes across at first glance is frustration (directed at the event itself, or its parameters), Student 5 seems sincerely to regret having been unable to make the most of the opportunity to communicate some of his inner life with the audience, to let them "take part" in his life, as he puts it. All he managed to do, he feels, was to give them a "hint"; all he said "remained on the surface." While he acknowledges that it was his decision to make his poem so short, Student 5 seems not to want to take full responsibility for this fact. He could have made his poem longer, or read a second poem as well, or even chosen a longer prose text (he had several options in his portfolio), which might have given him a more satisfying feeling of having connected with the audience. In short, although he did choose to participate in the Public Reading, he did so at the very minimum level, and now, afterward, he seems to regret that decision.

Student 4 presents an interesting contrast. He too was utterly opposed to the Public Reading from the very start, citing his "terror" at the very idea of reading creative work in front of an audience. As noted above, unlike Student 5, he located the source of his "displeasure" not in the plan for the Public Reading, but in himself, in his own lack of self-confidence. This bespeaks, at the very least, a degree of self-awareness that Student 5 seems to achieve only sporadically (and above all in his parenthetical remarks). Student 4, in his remarks on the Public Reading, takes the opportunity to reflect back, not only on these earlier feelings in the course, but on an entire personal history of such feelings, to which he had been subject, he says, since childhood. I would like to quote these remarks at length:

From the very first moment in which we were proposed to hold a public reading at the end of the seminar, I have never hidden my aversion. The reasons for my displeasure were several and of different nature. I have never been fond of public performances. I'm strongly convinced that performing requires a high level of self-confidence I don't believe I possess when it comes to expressing my feeling to an unknown audience. Surely being bullied as a teenager in occasion of the only school recital I ever took part in did undermine my self-confidence, and although many years have passed since then, I always feel slightly uncomfortable with the idea of performing in public. In addition, being the English language so intrinsically linked with my emotions, the idea of reading out my texts written in English simply terrified me. The trouble is that I have never been able to make a clear distinction between myself, who I am as a person and what I write, no matter whether it is an essay or a piece of creative writing. [...] So, when asked to hold a public reading, I found 
myself torn between the discomfort of performing in public, increased by the vexation of having to do it in English. After having mulled things over, however, I realized that my discomfort was more of a linguistic sort. I could have "easily" overcome the neurosis nurtured by the memory of teen-aged anxiety but I could not surely refuse to speak and write in English in an EFL-class. [Student 4]

This is in itself a rather remarkable example of memoir; but for our purposes here, it is illustrative of just how high the individual stakes can be for a performance, particularly in a foreign language, in which one is vulnerable in ways or to a degree beyond what one experiences as a native speaker. But by situating his "terror" in the context of a long personal history, Student 4 not only clarifies for himself (and for me) the real reasons for his aversion to the Public Reading, but also goes a certain distance toward overcoming it.

But these reflections, it is important to remind ourselves, came after the Public Reading. While it would be fallacious to assert without further ado that they came therefore because of the Public Reading, Student 4's further remarks about the experience of the Public Reading itself suggest that this might very well be the case. The story he chose to present was (unlike Student 5's short poem) both relatively long and extremely personal (albeit written in the 3rd-person): not the sort of text one would expect a student feeling vulnerable to the point of terror to read to an audience of strangers:

When it was my turn, I could not move. My hands were sweating and I just could not move from the chair, which is why I was the only one who read his text from the sofa. It was as if I had become a part of it, as if it was the chair itself holding those sheets of paper. I envied my classmates' nonchalance: they could go on the stage and "perform" so freely, they even look happy when they are done, I thought.

For a moment, while reading it, I felt as if I were alone in the room: of course I could hear some noise in the background but it was like being alone in a room that had no walls, nor doors or windows. It was a room of my own where I could hear myself reading. It was only when people started applauding that I realized what had just happened, my eyes dampened and I felt a shiver run down my spine. After having read my text I felt exceptionally good. Not only had my anxiety disappeared, but it became clear to me that the knot made of fears, memories, expectations, panic and apprehension that had been tightening all these years had finally started to loosen up. Through some very good feedback I got by the audience, I suddenly realize that what I had always thought of as a hindrance could actually be turned into a plus and knowingly vectored towards the epistemological possibilities offered by creative writing. [Student 5]

Thus Students 4 and 5 form an interesting dichotomy. While one responded to the ordeal or emergency of the Public Reading by doing the minimum necessary, and ended feeling frustrated and unfulfilled, the other embraced the personal danger with great courage, and underwent what can only be called a significant 
personal transformation. While it is not my business here to psychologize, I am tempted to see a connection between the degree of self-awareness of the individual student and that student's openness to the transformative power of theatrical performance. As his remarks make clear, Student 5 recognizes that the hindrance lies within himself, and that it has had a long and complex history. Student 4 accepts his aversion at face value, and while he makes some effort at justifying it on the basis of feeling "not really prepared," essentially what he's saying is, I don't like it; and he leaves it at that.

To sum up, we might say that although the students came to the Public Reading with varying degrees of fear or reluctance and with various concerns, they arrived at the other side having experienced a very positive, and in at least one case, personally transformative event. They felt pride and pleasure in their accomplishment; they developed a feeling of communitas, i.e. a sense of themselves as an ensemble of creative learners; and they learned things about both creative writing and performing, as well as about themselves, that can only be learned experientially. The one student whose experience differed significantly (Student 4) frames that difference in terms of a missed opportunity.

In all of these effects, moreover, the fact of the live theatrical audience-the audience of witnesses - was determinative, both as an anticipated encounter, and as an experienced reality. For all of the students, something happened in and through the performance that was surprising. In some cases, the surprise was fairly minor, on the order of a recognition that one can, in fact, perform without being crippled by nervousness, that it is in fact "not so bad" or even "fun" and "thrilling." In other cases, the discovery was more on the order of a revelation-about themselves and their own creativity, about the art of writing, or about the possibilities offered by live performance.

\section{What the Teacher Wrote}

For all of the skepticism (much of it justified) surrounding John Hattie's monumental meta-analysis of empirical studies, Visible Learning, his contention that a teacher's perception of his or her classroom and the students' perceptions are often at odds is to a certain degree born out by this study. Comparing the experiences recorded in the students' Course Journals with those recorded in my own Teacher's Log results in some interesting contrasts. While the students, as we have seen above, were overwhelmingly concerned about the actuality of the upcoming performance, with emotions ranging from excitement to anxiety to terror, my Teacher's Log reveals a different set of concerns. Above all, the theme of authority emerges as the focus of many of my entries.

To some extent, this is to be attributed to the fact that I was from the outset and quite consciously interested in decentering or displacing myself from the merely institutional position of authority vested in me as teacher. I did this in an attempt, first, to discover whether a more authentic kind of authority could emerge on the basis of my actual skills as a teacher and my (for lack of a better term) personal integrity, and second, to see to what degree the students would 
step up and take responsibility for their own learning. At numerous points, however, I felt that this experiment was backfiring:

An experiment (a "crypto-experiment"?): what will happen in the class now that I-in all the ways I know how-have stripped myself of/laid aside the formal supports of authority? Will I continue to have authority in the classroom? Are there forms of authority I cannot fully shed: age, mother tongue, knowledge, self-confidence, charisma (?). What if I wore a t-shirt to class? ${ }^{27}$

[After class] I sat in the middle of one of the longer sides of the seminar table. ([Student $\mathrm{X}]$ sat, as it were, at the head of the table.) This choice seemed to have a profound effect upon the internal dynamics of the class. The discussion was lively, and at many points heated-and [Student X] was directly involved in much of it. The other students addressed their remarks as much to [Student X] as to me. My "authority" in other words - or at least "centrality" - seemed thereby deeply truncated. Was it really? Did the students feel the same way? Did it bother them? What, in other words, was the actual effect of this shift on the quality of learning? [Teacher's Log]

The students, by contrast, seem not to have been concerned with the issue of authority at all. (In any event, the theme did not explicitly arise in their Journals.) Even where the situation in question was, in fact, a matter of authority-for example, with the question of whether or not the Public Reading was obligatory-the students understood it in democratic terms, in which their personal wishes were seen in relation to the group.

Of course the regrettable flip side of this was that I was more concerned with my own "experiment" in authority, and more broadly, with my own teaching, than I was with understanding the students' personal concerns in the moment. Perhaps because for me as an American, and as an experienced teacher and a performing artist, the idea of reading in front of an audience causes only minimal anxiety or stress, I seem to have underestimated the degree to which this was a factor for these students. I tended to see the reluctance and resistance of some students as a matter of either simple timorousness or, indeed, as a challenge to the entire premise of the course, and hence to my authority. Only two weeks before the Public Reading, did I finally begin to recognize (and mirror) the emotional situation of the students:

At this point, I'm anxious about the Class Reading. The students seem quite ambivalent about it, others openly resistant. And I too am ambivalent-mostly in response to them, but also, I think, because organizing such things is a hassle, the sort of task I'm not necessarily good at. On the other hand, I feel fairly confident that if we go through with it, they will benefit from the experience. So I'm faced with the dilemma of deciding whether to "push it through," or simply let it die for lack of enthusiasm on their part. Put it to a vote? A class debate? [Teacher's Log]

\footnotetext{
27 I normally wore a sport-coat, button-down shirt and tie.
} 
Thus the issue of authority-whether to "push it through" or put it to a (presumably) doomed vote-remained central for me even at this late date.

The turning point, significantly, seems to have been the class period immediately prior to the Public Reading, which was devoted to a kind of practical "performance workshop." Each student—on a volunteer basis-was given an opportunity to "rehearse" their reading in front of the rest of us. This involved going to the front of the classroom and either standing or sitting, while the rest of us took on the role of "audience." Then followed a brief "feedback session" for each reader, focusing on such issues as pacing, volume, pronunciation and enunciation, and physicality; the intention being to help each student become more fully aware of his or her own performance, such that weaknesses as well as strengths could be identified and, where necessary, rectified. During this "rehearsal," most of the students seemed quite uncomfortable. ${ }^{28}$ But in the end, the exercise seems to have had a profoundly positive effect, both on the individual students and on group morale. Thereafter, everyone was officially "on board" for the Public Reading.

On some level, however, I continued even thereafter to be concerned about the Public Reading, rather in the manner of a producer: I was worried about attendance. This was due to two factors: 1) it had become clear that the students themselves were reluctant to invite their friends, hence if they were to have any kind of "audience" at all-an essential part of the experience of performance, in my view-I would have to drum one up for them; and 2) as a new faculty member, I wanted the event to be seen as a "success" by my colleagues in the Institute for English Language and Literature. ${ }^{29}$ I took steps to publicize the event, both through the departmental email list-serve and by putting up posters and fliers around public spaces in the Institute.

Was also surprised that several of my colleagues reacted positively to my announcement of our event. Apparently such things really are unusual-though it's nothing special at all. It would be nice if a few of them actually showed up. - The general sense that it doesn't actually take all that much, if one is willing to do a little extra and "give of oneself." [Teacher's Log]

My experience of the reading itself was also rather more that of the "producer." I was at first disappointed to see, in the end, so few audience in attendance. (There were approximately 20.) And since I was only dimly aware, going into the event, of the true extent of the personal and emotional stakes for many of the students, I was also not particularly well-attuned to the intensity of their experience at the event itself. Moreover, again as a more experienced performer,

\footnotetext{
${ }^{28}$ I noticed all of the typical signs of this: shaking hands, flushed or splotchy skin, quavering voices, perspiration.

29 This desire was, I trust, less rooted in personal vanity than in the belief that my colleagues might actually enjoy seeing their students in a different curricular context, and would perhaps as a result consider such "creative" work at the university in a more positive light. This I note in the spirit of full disclosure of my own "ideological orientation."
} 
I was more cognizant of / concerned with my own performance as Master of Ceremonies than I perhaps ought to have been:

The reading yesterday-more lightly (i.e. less well-) attended than I'd hoped, but in the end the atmosphere was positive. The students seemed to get something important out of it-they were nervous, I could tell, but prepared, and took their "roles" seriously. Several came up to me afterward and thanked me for my help-and some of the audience did too, among whom were a handful of colleagues. A success, overall, though perhaps a minor one. (I was most dissatisfied with my own "performance" introducing and moderating the event. I'd planned to recite [William] Stafford's [poem] "The Way It Is" as an invocation and dedication, but didn't do as well as I'd hoped. I suppose it's "been a while now" since I've performed.)

Some food for thought: why didn't the students invite more of their friends? Were they somehow ashamed? Afraid of embarrassing themselves? Of being judged or criticized? Possibly. Hopefully a positive experience like this will begin to change that. [Teacher's Log]

\section{Summary}

The upshot of comparing my notes with the students' own written testimony is to take cognizance of a marked discrepancy. This is rather sobering. I simply was not sufficiently aware of the depth and complexity of emotion the students were experiencing with regard to the Pubic Reading. I "read" their reluctance as resistance (a questioning of my authority), or else as cowardliness, or worse: laziness. In certain respects, this was due to my taking at face value their own verbal expressions in class: the Public Reading was "extra work," it was "scheduled at a bad time," "no one would attend," it "should be optional," it was "something we're not trained to do," "I hate performing," etc.

At the very least, this was an error of judgement. But in truth it was more than that: it was also a failure of empathy and imagination. For me personally, as an experienced teacher and theatre artist, the Public Reading may very well have presented little occasion for anxiety, but for students who had perhaps never "performed" creatively before, it clearly and quite legitimately did. Had I been less concerned with my own "crypto-experiment in authority," I might have picked up other cues and known how to interpret the students' reluctance correctly: as a symptom of actual fear. Then the task would have been to address that fear directly, to work with it, and to help the students build up both the personal courage and the performative skills necessary to managing their fear in healthy and productive ways.

In short, the reality (both as imagined beforehand and then as experienced) of the Public Reading set off a significant emotional process in the students, one that I, though an experienced teacher and performer, failed fully to recognize and hence to harness and guide. And yet, despite this partial failure on my part, the students experienced the Public Reading as an extremely positive form of learning, and indeed, as transformative. 


\section{What the Data Mean for EFL Teaching}

The qualitative data I have examined here shed little direct light on the effectiveness of Creative Writing as a technique for teaching English as a Foreign Language per se. ${ }^{30}$ But they do shed a fair amount of indirect light. Although at this point in their lives the students were not themselves studying EFL (at least not explicitly), but rather the teaching of EFL, still it must be noted that they were students, i.e. learners, and that they were still learning in what was, for them, a foreign language. Thus one might speak of a structural parallel between them and their own future EFL students. Moreover, because the method of the course was oriented toward the practical (the students performed the creative writing exercises just as though they were actual EFL students), their experiences, I would argue, tell us something significant about the possible effects of these techniques in the EFL classroom. ${ }^{31}$ This is particularly true on the matter of performance.

What we see from the data is that the experience of performance, both in terms of the practical orientation toward it over time and the final realization of it, induces a deep investment of emotion. Only one student reported a lack of affect in the run-up to the Public Reading, and during the reading itself his affect was, by his own testimony, quite strong. Moreover, these emotions were not trivial or short-lived, but sustained, fundamental/existential, and dynamic. They tended, moreover, to follow a certain trajectory: from stress to release, from anxiety to happiness, from diffidence to confidence, from fear to courage to pride. What prevailed at the end was a sense of accomplishment, a realization of heretofore unknown competence and strength, and an ensemble feeling.

The polarity of these emotions is of potential interest as well. In other words, we are not speaking here of exclusively "positive" emotions; nor was the experience merely "fun." Far from it. As we have seen, some students experienced emotions that can only be described as negative, unpleasant, even painful. But what we see is that these negative emotions actually seem to have opened the pathway for positive emotions in and through the performance. In dramatic terms, one might speak here of the personal stakes for each student: those with the most at stake initially (e.g. Student 4, whose "terror" had to be met with great "courage" before he could participate in the Public Reading at all) stood to gain the most by the end. Far from being a subtraction in the calculus of learning-benefits, the negative emotions formed an essential moment in the experiential trajectory. One is tempted to see the negative and

\footnotetext{
30 Since this question was, however, the explicit topic of many of the writing prompts and discussions in class, the Course Journals do contain a wealth of data. Though I have not examined these data in this Preliminary Study, a companion study will address the topic in the future. For our present purposes, suffice it to say that the students were overwhelmingly of the opinion that the exercises they were being asked to do could find effective use in an EFL classroom.

${ }^{31}$ It seems plausible that these techniques would be no less effective in the teaching of other foreign languages besides English, or of other academic subjects entirely, even where language is not the main focus.
} 
the positive in a direct proportion or symbiosis.

A different study, involving actual EFL students, would be necessary to determine whether in fact this experience carries over into the EFL classroom. Numerous factors would also have to be considered, above all the age of the subjects. The subjects here were not children, pre-teens or teenagers obliged to learn English in school, but aspiring teachers in a professional training program at a major research university. Nor is it irrelevant that the career to which they aspire is (and is now increasingly understood as) a thoroughly performative one. ${ }^{32}$ While some of the students sampled here seemed not fully to appreciate this fact, it stands to reason that on a basic level, they were capable, even prior to taking the course, of picturing themselves in front of an "audience," at least an audience of pupils in a classroom. Thus they could be seen as a self-selected cohort, i.e. as not representative of the "average" EFL student, whether in school or in an adult language program.

Despite this, however, and without exception, all of the students viewed the Public Reading as a significant personal challenge-in some cases and for a certain amount of time as an insurmountable one. And with only one exception, they all experienced a sense of personal validation as a result of the Public Reading itself. While the population sample was far too small to warrant positing any general validity to this emotional trajectory vis-a-vis public performance, the data do tend to confirm the conventional wisdom that the moment of public performance (in every sense) is a kind of crucible: an intensely "educational" encounter, in which the performer learns things about herself that would be difficult to learn any other way.

But the effects of the public performance of original work (as was the case with this course) seem to go beyond mere self-discovery and "validation." What seems to be involved is a "fruitful moment" of the kind described by Friedrich Copei: a moment which opens the door to personal transformation. ${ }^{33}$ It is in this way that we might consider performance as a secular, but structurally complete, rite de passage. Students emerge from the experience having undergone an "existential change," passing, as it were, from "raw" to "cooked" through the heat of theatrical performance.

\section{What the Data Mean for EFL Teacher Training}

On a very practical level, it would be easy to argue that courses like the one described above ought to have a significant place in EFL teacher training

\footnotetext{
32 People with a crippling fear of public speaking, for example, do not generally choose teaching as a profession, unless they are bound and determined to overcome that fear, or (unlikely but still possible) unless they have somehow managed to get through years of their own schooling without realizing that what they've been witnessing from their desks is a series of more or less successful performances.

33 'The 'fruitful moment,' in all its many forms, is the point of the deepest and most spirited understanding of meaning, and expression of meaning. It is from this point of the highest vibrancy, abundance and creativity that transformative effects enter into the soul, building up that gestalt which we can call true education" (Copei 1963: 101).
} 
curricula, first, because creative writing offers an effective set of tools for the EFL classroom, and second, because anyone wishing to use creative writing as a pedagogical technique were well advised to have first-hand experience with it. Theoretical knowledge alone does not suffice, since what is involved in such creative activities is in fact a certain kind of experience. We can call it an aesthetic experience, an artistic process, etc.; but without having had that experience herself, an EFL teacher would be unprepared to deal with the potentially volatile emotions that such experiences, by their very holistic nature, tend to activate-particularly in young people. In other words, a teacher needs to know the territory first-hand before sending students into it with a map, however up-to-date, digital and interactive that map may be. It is no simple matter to encourage the creative process in people who don't necessarily think of themselves as creative, and to respond honestly and constructively to the products of that process. Teachers wishing to do this in their classes ought to receive the appropriate training-which means, in essence, hands-on artistic training.

This is of course precisely what is being called for with increasing urgency in the academic field of Teacher Education. Manfred Schewe's recent plea for "a performative pre-service and in-service teacher training" for foreign language teachers (Schewe 2011: 22; my translation) finds broad resonance in other disciplines. What is interesting to me, coming to this discussion as I do from the "outside" both culturally and in terms of academic and artistic training, is the obviousness of it. That the best teachers are also consummate performers is plain to anyone who cares to look, although the styles of performance may vary tremendously. ${ }^{34}$ The question of course is how such performative Kompetenz ${ }^{35}$ is to be taught in Schools of Education, or more pointedly, who is to teach it. But if we are serious about teaching as a performing art, then the answer is clear: the teachers of teachers ought to include well-trained and professionally experienced performing artists.

Does this mean that training in methodology, education theory, child psychology, etc. should be dispensed with in favor of workshops in improvisation, voice and movement? By no means. Both are needed; to suggest otherwise would be as silly as telling an aspiring writer she needn't bother reading and studying literature, or for that matter, using a dictionary. But a writer also (and I would argue, more fundamentally) needs to develop a living connection to her own creativity. Otherwise she is just a scribe.

\footnotetext{
${ }^{34}$ In the United States, moreover, teachers are expected to be "performers" in several ways simultaneously: they are expected to "entertain" their students, and they are expected to "get results," i.e. to attain certain specific goals or obtain certain specific "outcomes," as measured by their students' performance on standardized tests. It would not be difficult to trace both of these pressures to economic factors: to the sheer expense of higher education in the U.S. and the consequent evolution toward a corporate or business model for education administration. The viral and talismanic ubiquity of words like "assessment" in such discussions is indicative enough. This trend seems to have had a quite detrimental effect on the morale and sense of personal authenticity among North American university professors (Vannini 2006).

35 The phrase is Wolfgang Hallet's, which he glosses as a "Mitgestaltungsfähigkeit von Interaktionen" (Hallet 2010).
} 
But the data from this preliminary study suggest something more. The real value of such experiential artistic training lies not in the fact that it informs future teachers about how best to deploy creative processes in their own classrooms, nor even in the fact that it helps future teachers become better performers, but in the fact that it transforms the future teachers themselves. It is, to return to an idea I suggested earlier, a form of initiation.

On one level, the teacher-in-training experiences through theatrical performance just what her future students will experience: a holistic engagement of body, intellect, emotions, and imagination in the crucible of an audience's attention, an entry into a dynamic encounter with a group of witnesses that will change the performer, expand her awareness, strip away false ego-forms, and bring her closer to a sense of personal authenticity and hence personal authority.

But the teacher-in-training is transformed on a different level as well, a level that relates directly to her chosen profession. For the teacher, the experience of theatrical performance is transformative not merely in the general way that it can be for anyone, but in a way that relates quite specifically to the performative art known as teaching. Here I am not speaking of the many ways in which the teacher's craft resembles (and hence can benefit from) the actor's craft. This seems clear enough to anyone with experience in both. ${ }^{36}$ What I would like to suggest is rather that personal authenticity itself is a performance. It is not a "role" in the dramatic sense (that would be the opposite of authentic); but it is a performance in the sense that it involves both the manifesting and the conscious owning, before witnesses, of the person one really is. This is nowhere more evident than in the public performance of original work. There is simply nowhere to "hide"-certainly not behind methodology. Nor even behind personal charm or "charisma." And like any theatrical audience, the pupils in a classroom know-because they feel it-whether or not their teacher is authentic.

In this way, teaching might be seen as fundamentally the art of performing authenticity. Teachers are called upon to engage authentically with the very real, embodied, spontaneous, unpredictable, and endlessly fascinating audience of pupils in front of them. What performer and audience co-create is that special kind of event called learning. The teacher who cannot perform, who cannot bring her full authenticity into this circuit of co-creation, risks losing not only her own natural authority, but any chance of connecting authentically to her pupils. $^{37}$

\footnotetext{
${ }^{36}$ For a cogent (though not complete) summary of these benefits, see Mark Almond's short essay, "The Art of Language Teaching: What Teachers Can Learn from the Actor's Craft," (Almond 2014).

37 A significant loss, in light of John Hattie's discovery that the "quality of teacher-student relationships" is one of the most important factors in determining educational outcomes. C.f. Chapter 7, "The Contributions from the Teacher" in Hattie's Visible Learning: "The most critical aspects contributed by the teacher are the quality of the teacher and the nature of the teacherstudent relationships" (Hattie 2008: 126).
} 


\section{Conclusion}

Toward the end of his voluminous study, The Art of Foreign Language Teaching, Peter Lutzker reflects upon the personal growth many of his students experienced in connection with a class production of The Diary of Anne Frank in dramatic adaptation. He points directly to the creative experience itself: "[T]hose artistic processes which led to significant personal developments cannot be separated from their collaborative realization in performance with and for others." (Lutzker 2007: 461)

This with and for is essential. While there can no longer be any doubt that class-time devoted to carefully-designed creative, artistic or aesthetic activities is time well-spent (whether we are speaking here of the foreign language classroom or of classrooms in other disciplines, including Education), the present study would suggest that such activities offer their greatest benefits when culminating in some form of public (i.e. theatrical) performance, a performance "with" one's peers and "for" the larger community, however defined. Although the immediate aim is "effective teaching and learning," the more essential aim, and the more far-reaching one, is a personal transformation toward authenticity: what the psychologist Carl Rogers some time ago called "becoming a person."

If we take this as the ultimate aim of education, then surely it ought to be consciously addressed in the education of educators. After all, the most important medium of teaching is the teacher herself, who she is as much as what she knows: her authenticity as a human being. And that authenticity must be performed - both in the classroom and outside it.

\section{Reflections}

In the interest of future research, I think it appropriate here to mention a few important methodological lessons that I, as teacher/investigator, feel I've learned "the hard way" through conducting this study.

The first has to do with language. In retrospect, it was certainly a mistake to have indicated on the syllabus that the Course Journals were to be written entirely in English. Although I tried in class to suggest that this was not a hard-and-fast rule, and that the important thing was for the students to write in whatever language seemed appropriate to the task at hand, I'm afraid that this only confused them. In any event, they chose unanimously to "play it safe" and do all their work in English. Presumably this had the benefit at least of giving them practice composing in English; and this was certainly appropriate for the more traditional creative writing prompts as well as for the formal assignments. But when it came to the reflections-such as the two prompts used as the basis for this study - it would have been much preferable for them to write in German, their native language, since what was being "assessed" there was not 
their proficiency in English, but their subjective experience. ${ }^{38}$ With only one exception [Student 4], the students' command of English turned out not to be sufficient to express much in the way of subtlety of emotion, at last not on short notice in class. I suspect that a great deal of actual experience was lost from view this way, simply by the students' inability to find words to express the full range and nuance of their feelings. ${ }^{39}$ That is certainly regrettable.

A second lesson has to do with the way the course was structured. Instead of one reflection prompt before the Public Reading and one after, it would have been preferable to ask the students to reflect upon the Public Reading several times throughout the term, beginning perhaps on the first day the idea was presented to them, with the last one then falling several weeks after the term had ended. I might even have added one immediately before and immediately after the Public Reading itself. Assuredly, this would have given me a fuller and more nuanced picture of the trajectory and/or evolution of their emotions, even if only to the extent of confirming what the two prompts I did give already show.

And lastly, a lesson on pedagogy: given that the one "rehearsal" we had, during the class period prior to the Public Reading, produced such salubrious results in terms of the quality of the presentations, the individual students' self-confidence, and in the general group morale, it would have been smart to devote more time to this kind of practice over the course of the term. Instead, we spent most of our class time on craft, i.e. doing creative prompts and workshopping each other's formal writing, or else discussing the usefulness of these activities for the EFL classroom. No one, in short, was required to get up from his desk very often. The opportunity to "try things out" performatively, albeit in the relatively safe environment of the familiar classroom, and to receive constructive feedback on one's performance, turned out to be just as important as rehearsal is for the actor, musician, or dancer. The students needed more of it. They would have gone into the Public Reading feeling more self-confident, more self-aware, more able to respond spontaneously to the moment of live performance, and hence more open, one imagines, to the transformative possibilities it offers.

\footnotetext{
38 This is based on the perhaps contentious assumption that subjective experience is more fully disclosed (made "objective") through one's mother tongue than through a foreign language, even one in which one has reached a high level of fluency; which in turn assumes that subjective experience is somehow "given" prior to its verbal expression. Many practicing creative writers will tell you, on the contrary, that language informs subjective experience even as it is being used to perform it as expression. As the $20^{\text {th }}$ Century American poet William Stafford writes, "A writer is not so much someone who has something to say as he is someone who has found a process that will bring about new things he would not have thought if he had not started to say them." (Stafford 1978: 17)

${ }^{39}$ Naturally I can't prove any of this. But the fact that the one student whose English fluency was at or near the native-speaker level wrote more than any other in response to the two prompts raises the possibility that the others too may have had more to say.
} 


\section{Bibliography}

Almond, Mark (2014): The Art of Language Teaching: What Teachers Can Learn from the Actor's Craft. In: Performing Arts in Language Learning: International Conference Proceedings. Rome: Edizioni Novacultur, 38-43

Athiemoolam, Logamurthie (2013): Using Drama-in-education to Facilitate Active Participation and the Enhancement of Oral Communication Skills among First Year Pre-service Teachers. In: Scenario: Journal for Drama and Theatre in Foreign and Second Language Education 2013/2, 47-61

Brook, Peter (1968): The Empty Space. New York: Touchstone

Copei, Friedrich (1950): Der fruchtbare Moment im Bildungsprozeß. $7^{\text {th }}$ ed.). Heidelberg: Quelle \& Meyer

Dewey, John (1934): Art as Experience. New York: Perigee Books

Eisner, Elliot (1985): Educational Imagination: On the Design and Evaluation of School Programs. (2 ${ }^{\text {nd }}$ ed.). New York: Macmillan

Eliade, Mircea (1975): Rites and Symbols of Initiation: The Mysteries of Birth and Rebirth, trans. Willard R. Trask. New York: Harper and Row

Fischer-Lichte, Erika (2004): Ästhetik des Performativen. Frankfurt: Suhrkamp

Hallet, Wolfgang (2010): Performative Kompetenz und Fremdsprachenunterricht. In: Scenario: Journal for Drama and Theatre in Foreign and Second Language Education 1, 5-18

Hattie, John A. C. (2008): Visible Learning: A Synthesis of Over 800 MetaAnalyses Relating to Achievement. London: Routledge

Lessinger, Leon \& Gillis, Don (1976): Teaching as a Performing Art. Dallas: Crescendo Publications

Lutzker, Peter (2007): The Art of Foreign Language Teaching: Improvisation and Drama in Teacher Development and Language Learning. Tübingen: Francke

Mackey, Alison \& Gass, Susan (2005): Second Language Research: Methodology and Design. New York: Routledge

Merriam, Sharon (1998): Case Study Research in Education: A Qualitative Emphasis. San Francisco: Jossey-Bass

Rogers, Carl (1961): On Becoming a Person: A Therapist's View of Psychology. Boston: Houghton Mifflin 
Rubin, Louis (1985): Artistry in Teaching. New York: Random House

Sambanis, Michaela (2013): Fremdsprachenunterricht und Neurowissenschaften. Tübingen: Narr

Sarason, Seymour (1999): Teaching as a Performing Art. New York: Teachers College Press

Schechner, Richard (1988): Performance Theory. London: Routledge

Schewe, Manfred (2013): Taking Stock and Looking Ahead: Drama Pedagogy as a Gateway to a Performative Teaching and Learning Culture. In: Scenario: Journal for Drama and Theatre in Foreign and Second Language Education 2013/1, 5-23

Schewe, Manfred (2011): Plädoyer für eine performative Lehr- und Lernkultur. In: Küppers, Almut; Schmidt, Torben; Walter, Maik (eds.): Inszenierungen im Fremdsrpachenunterricht: Grundlagen, Formen, Perspektiven. Braunschweig: Bildungshaus Schulbuchverlage, 20-31

Schewe, Manfred (1993): Fremdsprache inszenieren: zur Fundierung einer dramapädagogischen Lehr- und Lernpraxis. Oldenburg: Zentrum für pädagogische Berufpraxis

Schiller, Friedrich (2004): Über die ästhetische Erziehung des Menschen. Stuttgart: Verlag Freies Geistesleben

Stafford, William (1978): A Way of Writing. In: Writing the Australian Crawl: Views on the Writer's Vocation. Ann Arbor: University of Michigan Press

Steiner, Rudolf (2004): Pädagogik und Kunst. In: Kiersch, Johannes (ed.) Texte zur Pädagogik aus dem Werke von Rudolf Steiner: Anthroposophie und Erziehungswissenschaft. Dornach: Rudolf Steiner Verlag

Thiem, Annegret (2014): Interkulturelle Kompetenze als Herausforderung für das Lehramtstudium. In: Scenario: Journal for Drama and Theatre in Foreign and Second Language Education 2, 44-61

Timpson, William \& Tobin, David (1982) Teaching as Performing. Englewood Cliffs: Prentice-Hall

Turner, Frederick (1985): The Neural Lyre. In: Natural Classicism. New York: Paragon House Publishers

Vannini, Phillip (2006): Dead Poets' Society: Teaching, Publish-or-Perish, and Professors' Experiences of Authenticity. In: Symbolic Interaction 29/2, 235-257

van Gennep, Arnold (1908): Les rites de passage. Paris: Nourry

Weber, Ernst (1907): Ästhetik als pädagogische Grundwissenschaft. Leipzig: Wunderlich 